\title{
Mushroom refinement endeavor auspicate non green revolution in the offing
}

\author{
SHAUKET AHMED PALA ${ }^{1, \boldsymbol{v}}$, ABDUL HAMID WANI ${ }^{1}$, ROUF HAMZA BODA ${ }^{1}$, BILAL AHMAD WANI ${ }^{2}$ \\ ${ }^{1}$ Section of Mycology and Plant pathology, Department of Botany University of Kashmir, Hazratbal Srinagar-190006, Jammu and Kashmir, India. \\ Tel: +91-9858709043; `email: sapala29@gmail.com. \\ ${ }^{2}$ Centre of Research for Development, University of Kashmir, Hazratbal Srinagar-190006, Jammu and Kashmir, India.
}

Manuscript received: 22 August 2014. Revision accepted: 2 October 2014.

\begin{abstract}
Pala SA, Wani AH, Boda RH, Wani BA. 2014. Mushroom refinement endeavor auspicate non green revolution in the offing. Nusantara Bioscience 6: 173-185. Mushroom can serve as food, tonic, and as medicine thus make people healthier, fitter and happier. They have a cracking potential for generating great socioeconomic impact in human welfare at local, national and international level. With the help of allied mushroom farming we can easily tackle the problem of food for growing world population; reduce environmental pollution by bioconversion of huge organic wastes into mushrooms; recycle huge quantity of organic wastes to mushroom crops, biofertilizers, and biogas; restore damaged environment by mushroom mycelia through mycoforestry, mycoremediation, mycofiltration and mycopesticides in a zero emission fashion. They can be used to degrade radioactive industrial biocide wastes in an eco-friendly fashion. Since mushroom cultivation is an indoor agribusiness, it could have great economic impact by generating employment, income and functional food requirements for rural people especially in developing countries. How far mushroom cultivation can meet the functional food requirements; address the domestic food challenges, rising food prices and crisis vis a vis environmental sustainability will be thrust areas of this communication.
\end{abstract}

Keywords: Medicinal value, mushroom cultivation, non green revolution, production.

\section{INTRODUCTION}

Prior to touching the multitude affairs of mushrooms for human welfare on this biosphere we need their proper introduction. The word 'mushroom' is a loosely-used term that actually refers to the macroscopic fruiting body of fungus. The fruiting bodies are extremely diverse in form; some look amorphous globs of jelly, while others are umbrella like, reminiscent of coral, egg like, birds nest like, starfish shaped etc. One of the most widely accepted definition regarding mushrooms is stated by Chang and Miles "Mushroom is regarded as a macrofungus with a distinctive fruiting body, that can be either epigeous or hypogeous and large enough to be seen with naked eye and to be picked by hand" (Chang and Miles 1992). They mostly belong to class basidiomycetes and ascomycetes of Kingdom fungi. Current studies estimate that out of 1.5 million species of existing fungi, 14,000-15,000 species produce fruiting bodies of sufficient size and suitable structure to be considered as mushrooms (Hawksworth 2001). Of these, about 7000 species are considered to possess varying degree of edibility, and more than 3000 species from 31 genera are regarded as prime edible mushrooms and some 2000 species have medicinal attributes. Contrary to this vast diversity only a handful of species have been exploited by mankind for human welfare and there are about 100 of them grown experimentally, 50 economically cultivated, around 30 commercially cultivated, and only about 6 have reached to industrial scale of production (Chang and Miles 2004). Though this diversity is fouled by some poisonous mushrooms which are clumsy but their number is relatively small (approximately 10\%), of these some 30 species are considered to be lethal.

\section{MUSHROOMS OFFER A RAINBOW OF PRODUCTS AND SERVICES}

Mushrooms offer a range of food products, medicines and ecological services. Their medicinal and food value is an intermingling area of functional food products. Mushrooms act as a balanced food for all ages. In health sector mushrooms have proved their worth by warding off simple to severe diseases. Mushroom derived medicines have potential to increase immunity of our body thus reducing chances of disease susceptibility. Ecologically mushrooms play role of biofilters and biofertilizers. Mushrooms are important constituents of minor forest produce (secondary produce) and grow on the most abundant biomolecule of this biosphere known as cellulose. They can degrade, neutralize or accumulate pollutants of different kinds. They add to the fertility of soil without damaging it. A bird's eye view of these lineaments is as under.

\section{Nutritional value of mushrooms}

Mushrooms as food were used by man when he was still a food gatherer and hunter on the chronology of cultural evolution (Rojas and Mansur 1995; Kumari et al. 2013; Thatoi and Singdevsachan 2014). Edible mushrooms once called the "food of the gods" are still used to garnish the dishes and serve as functional food. Mushrooms are important source of quality protein, minerals and various novel compounds of medicinal value. They are rich sources 
of protein (20-30\%) with good digestibility and rank below animal meats, but well above most other foods (vegetables and fruit), including milk, thus aptly called mycomeat or vegetable meat (Wang et al. 2014). Mushrooms are also the source of energy foods - carbohydrates and fats; accessory food factors-vitamins; and inorganic compounds which are indispensable to good human health. Mushrooms are one of the best sources of vitamins being rich in thiamine (B1), riboflavin (B2), niacin, biotin and ascorbic acid (Ayaz et al. 2011). Due to low starch content and absence of cholesterol, they suit diabetic and heart patients. Mushrooms are rich in minerals like potassium, sodium and phosphorous. High potassium: sodium $(\mathrm{K}: \mathrm{Na})$ ratio in mushrooms; makes them ideally suited for hypertension patients (Chang and Miles 2004; Agrahar and Subbulakshmi 2004)). The moisture content of fresh and dried mushrooms varies from 70 - 95\% (depending upon the harvest time and environmental conditions), and 10 13\% respectively (Kansci et al. 2003). They are rich in dietary fibers that have various beneficial health effects to humans. In addition to nutritional value, mushrooms have some unique color, taste, aroma, and texture characteristics, which attract their consumption by humans. The Nutrient Value of some widely cultivated mushroom (Per 100 grams dried mushroom) is as (Table 1).

\section{Medicinal value of mushrooms}

The relationship between diet and disease summarized by father of medicine Hippocrates "Let food be your medicine and medicine be your food" suits good to mushrooms because of their marvelous nutraceutical value. Mushrooms have been found effective against cancer, cholesterol reduction, stress, insomnia, asthma, allergies and diabetes effectively (Waseer 2010, 2011). There are also increasing experimentally based evidence to support centuries of observations regarding the nutritional and medicinal benefits of mushrooms. The value of mushroom products has recently been raised up for encouraging results generated from trials conducted for HIV/AIDS patients (Nanba 1993; King 1993; Pala and Wani 2012). Edible wild or cultivated mushrooms possess commendable immunomodulatory nutriceuticals and dietary supplements to increase the natural immunity. The recent upsurges of interest in traditional remedies for various physiological disorders by the compounds and products from the mushrooms have led to the coining of the term "mushroom nutriceuticals" (Chang and Buswell 1996). From medicinal mushrooms the extractable products are designed to supplement the human diet not as regular food, but as the enhancer of health and fitness. A regular intake may enhance the immune responses of the human body, thereby increasing resistance to disease and or cause regression of an ailment (Chang and Buswell 2008).

Several biologically active compounds like high molecular weight polysaccharides that assign them immune enhancing and tumor retarding effects have been obtained from the cell wall of several medicinal mushrooms. It has been reported that the anti-tumor and anti-cancer effects of the mushroom polysaccharides are based on the enhancement of the body's immune system, like by activating macrophages, natural killer cells, cytotoxic $\mathrm{T}$ cells, and their secretory products, such as the tumor necrosis factor, reactive nitrogen and oxygen intermediates, and interleukins, rather than direct cytocidal effects (Smith et al. 2002; Israilides et al. 2008; Mallick et al. 2010; Camargo and Kaneno 2011). Triterpenoids, steroid-like compounds from Ganoderma spp. have been reported to conduce cytotoxic, hepatoprotective, and hypolipidmic influence on platelet aggregation, inhibition of angiotensine-converting enzyme, and inhibition of histamine release (Camargo and Kaneno 2011). Lectins (proteins or glycoproteins) exemplify another group of mushroom bioactive compounds with specific binding sites for sugars that own anti-tumour and immunomodulatory activities. Mushrooms are not known to affect the concentration of serum high density lipoprotein (HDL) cholesterol, but the reduction of serum total cholesterol by the mushroom diets is believed to be attributable to the fall in low density lipoprotein (LDL) cholesterol (Lohani 2012).

\section{Ecological services of mushrooms}

Ecologically mushrooms play an important role on this biosphere by breaking down plant and animal matter and solublizing the structurally complex compounds into the constituent elements of utmost importance and usage. They extend the nutritional zone of plants through mycorrhizal associations and restore the aspects of soil congenial for survival of bioentities (Stamets 2005). Their relationship with plants is manifested in three forms, viz. those that act on living plants called parasites and those that recycle dead plant materials called saprophytes (vegetable vultures) and finally those which are in symbiosis with their host plants are called mycorrhizal mushrooms. Mycorrhizal mushrooms

Table 1. Nutritional attributes of some wildly cultivated mushrooms (Crisan and Sand 1978; Chang and Miles 2004; Bernas et al. 2006; Suman and Sharma 2007; Barrosa etal. 2007; Boda 2009).

\begin{tabular}{lcccccc}
\hline \multicolumn{1}{c}{ Name of mushroom } & Carbohydrate (g) & Fiber (g) & Protein (g) & Fat (g) & Ash (g) & Energy (kcal) \\
\hline Agaricus bisporus & 46.17 & 20.90 & 33.48 & 3.10 & 5.70 & 499 \\
Pleurotus sajor-caju & 63.40 & 48.60 & 19.23 & 2.70 & 6.32 & 412 \\
Lentinula edodes & 47.60 & 28.80 & 32.93 & 3.73 & 5.20 & 387 \\
Pleurotus ostreatus & 57.60 & 8.70 & 30.40 & 2.20 & 9.80 & 265 \\
Volvariella volvacea & 54.80 & 5.50 & 37.50 & 2.60 & 1.10 & 305 \\
Calocybe indica & 64.26 & 3.40 & 17.69 & 4.10 & 7.43 & 391 \\
Flammulina velutipes & 73.10 & 3.70 & 17.60 & 1.90 & 7.40 & 378 \\
Auricularia auricula & 82.80 & 19.80 & 4.20 & 8.30 & 4.70 & 351 \\
\hline
\end{tabular}


donate fertilizers like nitrogen and phosphorus to partner plant thereby allowing them to colonize poor soils and pull otherwise unavailable nutrients from the soil. Mycorrhizal mushrooms can help in reforestation program to a great extent and ecologists have now admitted that a forest's health is directly related to the presence, abundance, and variety of mycorrhizal associations (Perry et al. 1987; Dell 2002). Saprophytic mushrooms that grow on waste particularly of agricultural origin can convert lignocellulosic wastes into the value added products such as food, medicine, feed fuel and fertilizer and recycle the wastes elements. The spent mushroom substrate (SMS) left after final crop harvest has many positive attributes still left for its potential uses. The material has been found to be a good nutrient source for field and horticultural crops because of its nutrient-status. Besides, it has a high cation exchange capacity (a measure of the amount of nutrients a medium can hold) and has a slow mineralization rate that held in retaining its quality as an organic matter.

The use of fungi/mushroom mycelia acts as tools for healing soil and help in protecting and regenerating the environment what Stamets (2005) called "mycorestoration", which is the use of fungi/mushrooms to repair or restore the weakened or damaged biosystems of environment. The processes of mycorestoration include the selective use of mushrooms for mycofiltration, to filter water; mycoforestry, to enact ecoforestry policy; mycoremediation, to denature toxic wastes; and mycopesticides, to control insect pests. Mycorestoration recognizes the primary role fungi/mushrooms can play in determining the balance of biological populations. Mushrooms via bioconversion processes ensue reutilization of spent substrates and transform the polluting substances into valuable foodstuffs (Beyer 2005; Noble 2005).They can accumulate and filter pollutants and act as one of the most promising and effective biosorbent of toxic heavy metals from radioactive nuclear fallout polluting water and soil, thereby act as neutralizers of pollutants (Das 2005; Kulshreshtha 2014). They are voracious decomposers of waste material due to the presence of extra cellular enzymes, thus utilized as mycofilters to degrade pollutants. The mushroom mycelia have the ability to degrade carcinogenic radioactive pollutants released into the environment as a consequence of human activity. Mushrooms can degrade lot of structurally different compounds like D.D.T and Lindane (Bampus and Aust 1987). Mecellia of mushrooms have been shown to biomeneralize uranium oxides, suggesting they may have applications in the bioremediation of radioactively polluted sites (Fomina et al. 2005).

\section{MUSHROOM CULTIVATION}

In the present world though science and technology has revolutionized every aspect of life but the diverse challenges and constraints faced in the form of global food crisis, population explosion, climate change damaging farming practices and shortage of land exposes the humans to extreme risk. The 20th century began with a world populated by 1.6 billion people and ended with 6 billion inhabitants- with most of the growth occurring in the developing countries. The growing world population is increasing by about 80 million people per year. At the present, about 800 million people in the world are living in poverty and facing quality food crisis. On the other hand, it has been observed that over $70 \%$ of agricultural and of forest products has not been put to total productivity, and have been wasted in processing. The emerging scenarios demand a paradigm shift and cutting edge initiatives in formulating and implementing the novel an innovative agricultural research programs. Integrating mushroom farming in the existing farming systems will not only supplement the income of the farmers but can contribute in achieving food security, nutritional and social security. Since the mushroom cultivation do not compete for land and have very high productivity per unit area and time, thus can occupy a prominent place to address the void of quality food requirements, health and environmental sustainability. Mushroom cultivation offers an added advantage to recycle agro-waste as carbon pool into good quality protein, much of which otherwise is burnt in the field. Mushroom being an indoor crop, utilizing vertical space offers solution to shrinking land and better waste utility. Commercial production of edible mushrooms represents unique exploitation of the microbial technology for the large scale bioconversion of the agricultural, industrial, forestry and household wastes into nutritious and valuable products. The present century is going to be a century of functional foods free from synthetic chemicals. Mushroom cultivation fits very well into this category and is going to be an important secondary agricultural vocation. To face the global challenges all available expertise and resources need to be utilized to make mushroom Industry competitive in the world market. In this direction stronger research and production linkages with research organizations, industries, progressive farmers and other organizations will be needed. Interactions between research institutions and the mushroom farmers/industry need to be strengthened for realizing the full potential of the frontier sciences. There is a need for genetic enhancement of cultivated mushrooms to develop better strains and scan the new wild new species through systematic exploitation of the germplasm. Development of technologies to prolong the viability, shelf life and ease in bulk transport of the ready-to-use spawn is also required. While introducing high yielding strains of mushrooms, their susceptibility/ resistance to pests and diseases needs to be evaluated before they are released for general cultivation by the growers.

The applied aspect of this scientific endeavour integrates various disciplines of science as well as the associated technological processes to secure maximum benefits from this artful effort (Mabuza 2014). The recent advances in the mushroom science comply with zero emission principle (Lohani 2012). The modern tools and techniques in the field of biotechnology aim to lead the production of new strains of mushrooms having high biological efficiency, wide ecological adaptability, long shelf life, least vulnerable to pathogenic attack and high nutraceutical value (Kamal 2011). 
People have harvested mushrooms from the wild for thousands of years for food and medicines but commercial cultivation of mushrooms dates 50-60 years back only (Kaul and Dhar 2007). Mushroom cultivation will serve as means of generating employment, particularly for rural women and youths in order to raise their social status. During off season it can provide additional avenues to the farmers that will definitely improve the economic standards of the people, thus considered as important cash crop. It is hoped that mushroom farming will become a very important cottage industry activity in the integrated rural development program, which will lead to the economic betterment of not only small farmers but also of landless laborers and other weak sections of communities. Roundthe year cultivation of different mushrooms in rotation under the seasonal conditions is going to play a major role in increasing as well as diversifying the mushroom production. Their cultivation under controlled conditions in comparison to other crop, abundance of raw material forecasts the possibility of being a major crop in coming years.

\section{Mushroom production in world and differences in production pattern}

Since mushroom consumption is popular all over the world, commercial cultivation is therefore equally important. Although mushroom cultivation science is centuries erstwhile, but their cultivation at commercial scale based on scientific principles is recent and dated few decades back. So far only a handful of species are cultivated widely on commercial scale. During the past 30 years the increase in production was exponential with Agaricus bisporus playing the centric role. There are around more than 60 countries known for cultivated mushrooms with Asian countries continuing to dominate world production and consumption (Chang 1998) however, consumption in the United States has increased sharply in recent years, providing potential opportunities for mushroom growers. In 2008 it has been estimated that an output of 3,497,290 tons of mushrooms were produced by different countries of the world among which the major players were China, USA, Netherlands, Poland, Spain, India, Italy, Canada, Ireland and Japan which produced $1,608,219,363,560,240,000,180,000,50,450,131,974$, $100,000,86,946,75,000$ and 67,000 tons respectively and the percentage of some major countries to the total world output is shown in Figure 1, indicating that China is the leading mushroom producer followed by USA (UNFAOSTAT 2011).

Mushroom farming is a beneficial agricultural practice that guarantee handsome return with least investment, but the route is yet at infancy. It has been estimated that over $70 \%$ of agricultural and of forest products have not been put to total productivity, and have been discarded as waste. If we exemplify India which produces about 600 million tons of agricultural byproducts, using $0.04 \%$ of these residues for mushroom has produced around 1.2 lakh tons of mushrooms. $1 \%$ use of these residues for mushroom production from this single country which does not figure significantly in international mushroom market can produce 3.0 million tons of mushrooms, which will be almost equal to current global button mushroom productioncurrent world production as per FAO is 3.4 million tons (Directorate of Mushroom Research India 2011).

When we retrospect the mushroom farming figures excluding china and USA most of the countries do not figure significantly as is evident from the Table 2 . Though the statistics depicts dramatic increases in the total world production of farmed mushrooms during the period 19612011, but booting out China and USA most of the countries are still lagging to touch the significant position in the mushroom production plausibly not because of the absence of raw material but largely due to inadequacy of understanding the vital roles mushrooms can offer in agricultural economy and conjuring up human health when used as dietary food supplements, lack of reliable sources of good quality mushroom spawn for supporting the efforts of local mushroom growers, lack of venture capital to support mushroom farming entrepreneurs, and absence of systematic government support towards promoting mushroom farming as a valuable non-traditional new food and cash crop.

When we examine the Table 2, it is quite evident that there is about sixteen fold increase in world production of farmed mushrooms but the growth is not uniform and positive in all countries. If we take the example of Austria the growth in production is not positive as the production in 1961, 1971, 1981, 1991, 2001 and 2011 has been calculated to be $3,000,3,000,4,100,2,700,300$ and 1,600 metric tons, same is the case with some other countries. Also proportion of increase in production is not in correlation with the increase in population growth thereby can't meet the demand. The production of mushrooms (metric tons) in different countries and continents from 1991-2011 (UNFAOSTAT 2011) is shown in Table 3.

The following statistics (Table 3) serve to illustrate disproportionate production of farmed mushrooms by different countries and continents. In 2011, Asia contributed $68.67 \%$ of the total world mushroom tonnage, Europe, $24.23 \%$, Americas $6.0 \%$, Australia $0.77 \%$ and Africa only $0.22 \%$ by producing 5301160, 1871076, 469832, 59580 and 17716 metric tons. In 2011China alone contributes the $64.88 \%$ of the world and $94.48 \%$ of Asian mushroom farm production.

It is a positive sign that there is constant virtual increase in the area utilized for mushroom harvesting and the mushroom production figures from 1991-2011, but when we examine the data (Figure 2 and Figure 3 ) it is quite evident that there is nearly about 3.5 fold increase in both area harvested for farming and total production, which indicates that there is not any significant growth in production efficiency (production per unit area). It is therefore inevitable to bring the fact on the path of research and point out the missing links and bridge the gap.

Though there are some 60 species of mushrooms cultivated in different countries of the World, but notable among them are Agaricus bisporus, Auricularia auricula, Calocybe indica, Flammulina velutipes, Ganoderma lucidum, Lentinula edodes, Pleurotus ostreatus, Pleurotus sajor-caju, and Volvariella volvacea (Figure 4). However, it 


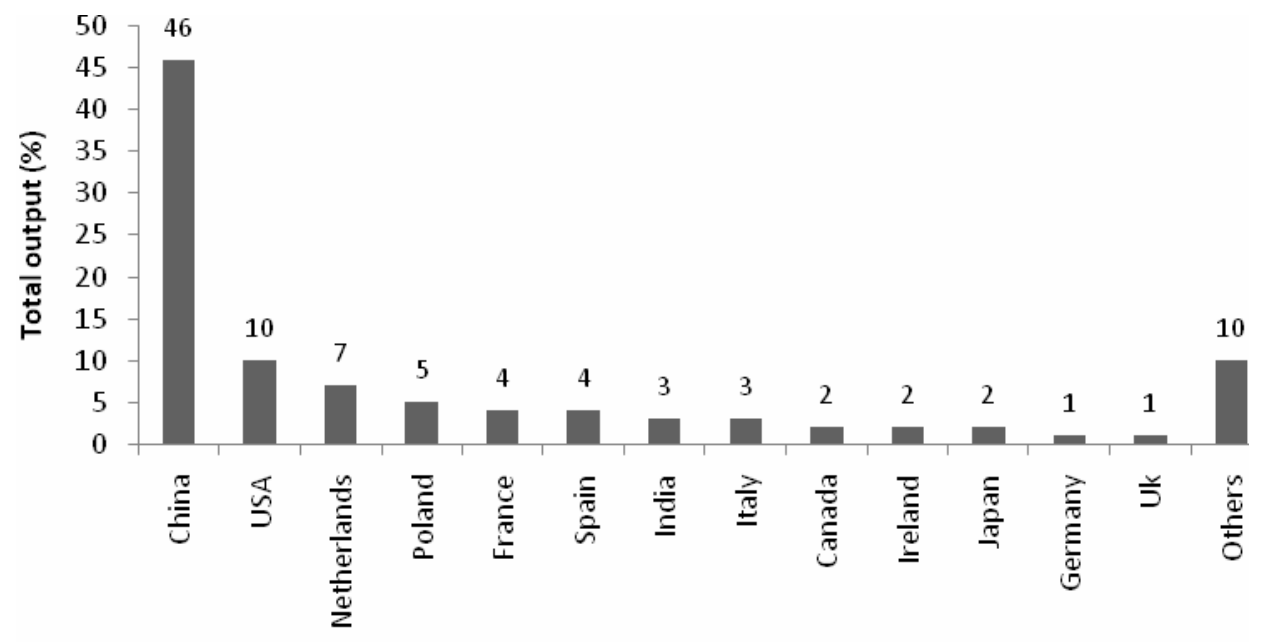

Country

Figure 1. Comparative mushroom production chart of World (UNFAOSTAT 2011).

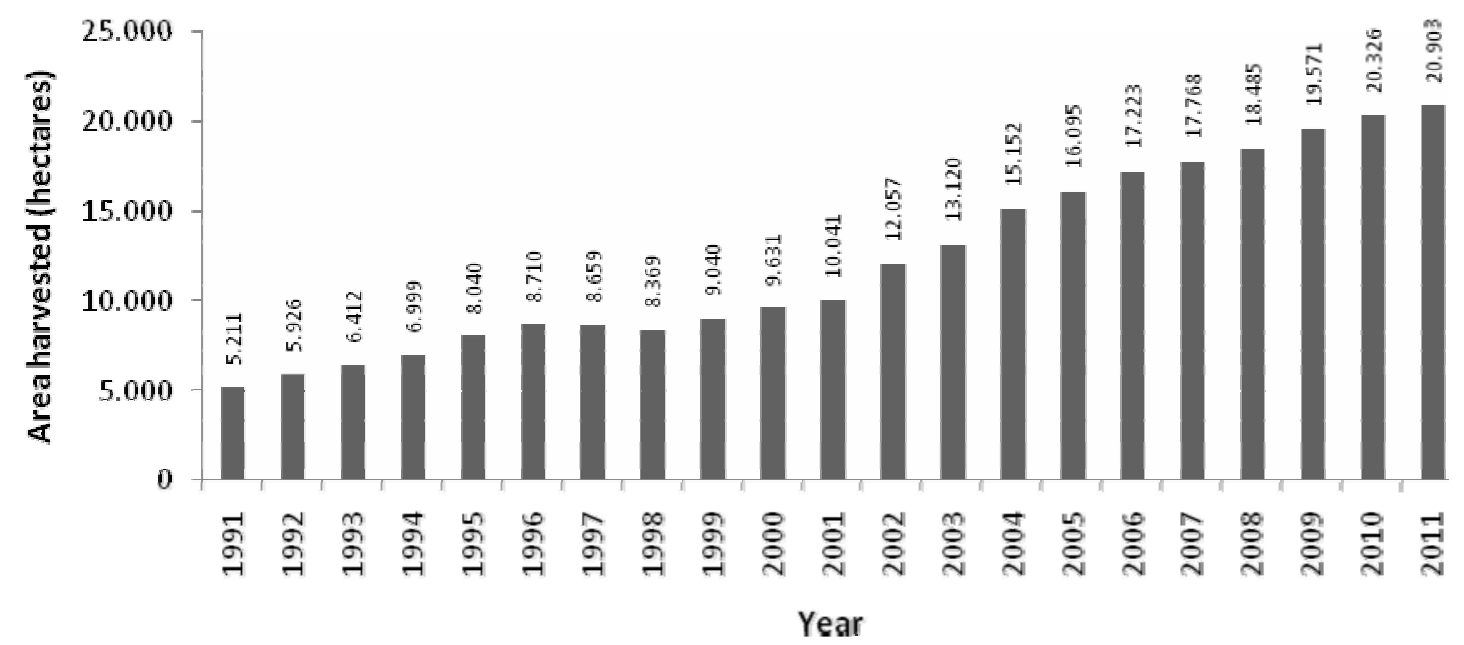

Figure 2. World mushroom production from 1991-2011 (metric tons) (UNFAOSTAT 2011).

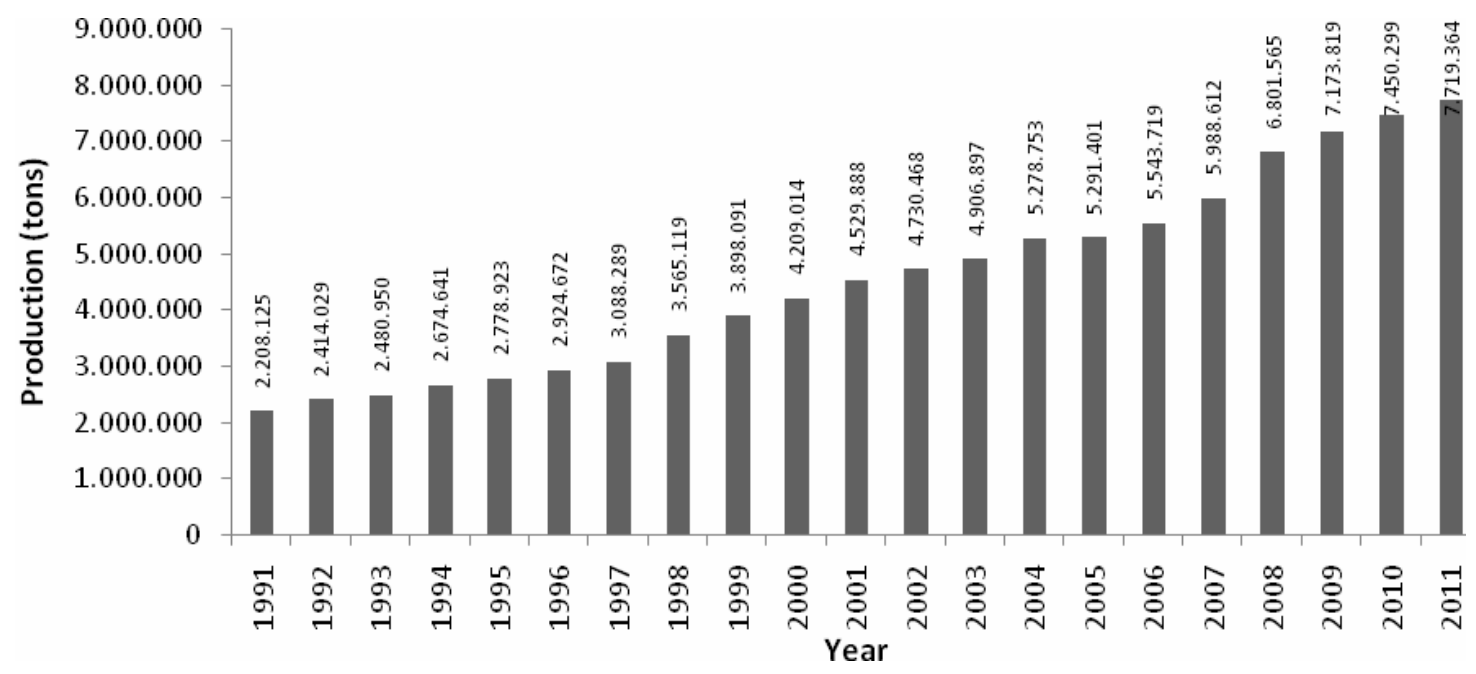

Figure 3. Area harvested for mushroom farming in World from 1991-2011 (hectares) (UNFAOSTAT 2011). 
should be noted that $A$. bisporus is only edible fungicultivated globally. In UK and in some other Western countries the mushroom industry is often overwhelmingly focused on one mushroom species i,e. A. bisporus. These industries are nearly $100 \%$ dominated by $A$. bisporus (Fletcher and Gaze 2008). In the US, it accounts for about $98 \%$ of its mushroom industry, Lentinula edodes for $1 \%$ and Pleurotus spp. for only about $0.5 \%$ (Table 4 ). Note: share of total US mushroom production is in brackets.

On the other hand, mushroom industry in Asia especially in East Asian countries are relatively less homogenized by A. bisporus as shown in Table 5 (shares of total mushroom production are in brackets). Agaricus accounted for $12.8 \%, 11.6 \%$ and $0 \%$ of total mushroom production in China, S. Korea and Japan respectively (in 2003). Agaricus, Lentinula and Pleurotus are the three important mushrooms that dominate the mushroom industry in Asian countries (Chang 2006; Cui 2004; Ho and Peng 2006).

\section{World mushroom market}

Mushroom farming is a business which necessitates practical experience, scientific knowledge, proper planning and support. The world market for the mushroom industry in 2001 was valued at over US\$40 billion. Production of mushrooms worldwide has been steadily increasing possible due to participation of developing countries, after realizing its efficiency in terms of agriculture returns per unit land, labor and money. The world market for the mushroom industry in 2005 was valued at over $\$ 45$ billion (Chang 2006). The 1999 US market for dietary supplements based mainly on mushrooms was estimated to be US\$35 million. From last few decades growth rate, both in terms of productivity as well as production has been phenomenal. The gross production value acquired by mushroom farming from 1991-2011 in different countries and continents is summarized in Table 6 .

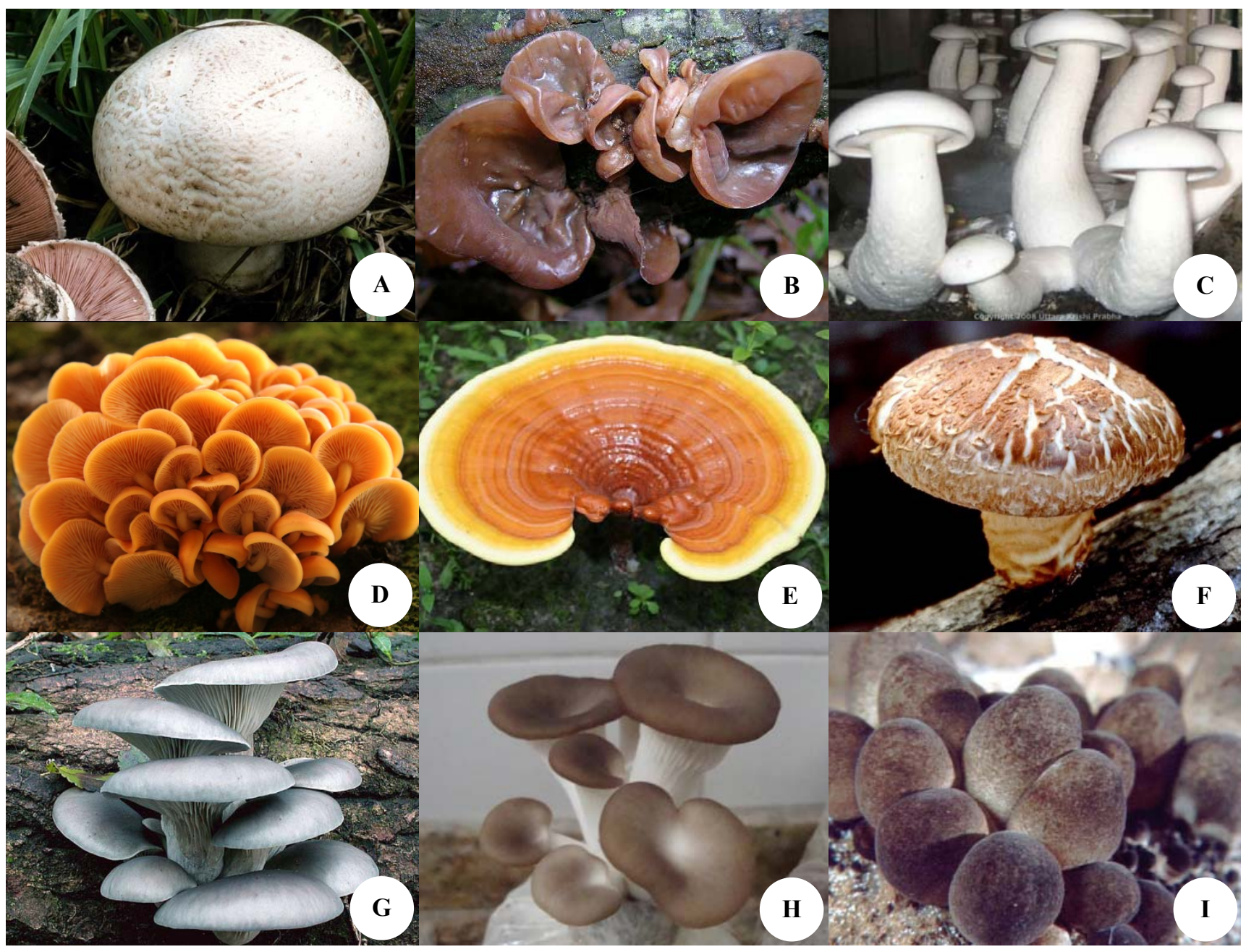

Figure 4. The world most notable cultivated mushrooms. A. Agaricus bisporus, B. Auricularia auricula, C. Calocybe indica, D. Flammulina velutipes, E. Ganoderma lucidum, F. Lentinula edodes, G. Pleurotus ostreatus, H. Pleurotus sajor-caju, and I. Volvariella volvacea. (photo from many sources) 
Table 2. World mushroom production (metric tons) (UNFAOSTAT 2011).

\begin{tabular}{|c|c|c|c|c|c|c|}
\hline Country & 1961 & 1971 & 1981 & 1991 & 2001 & 2011 \\
\hline Albania & - & - & - & - & 101 & 123 \\
\hline Algeria & - & - & - & 100 & 120 & 220 \\
\hline Australia & - & - & 8,265 & 24,394 & 39,394 & 49,696 \\
\hline Austria & 3,000 & 3,000 & 4,100 & 2,700 & 300 & 1,600 \\
\hline Azerbaijan & - & - & - & - & - & 1,700 \\
\hline Belarus & - & - & - & - & 8,000 & 6,500 \\
\hline Belgium & - & - & - & - & 40,500 & $41,, 556$ \\
\hline Belgium-Luxembourg & - & 4,500 & 12,408 & 20,592 & - & - \\
\hline Bosnia and Herzegovina & - & - & - & - & 800 & 994 \\
\hline Brunei Darussalam & - & - & - & 3 & 8 & 11 \\
\hline Bulgaria & 200 & 3,200 & 4,200 & 5,200 & 10,000 & 2,171 \\
\hline Canada & 7,800 & 14,622 & 32,709 & 53,020 & 86,357 & 78,930 \\
\hline China & $3,02,784$ & $4,22,422$ & $4,01,947$ & $7,95,013$ & $26,69,841$ & $50,08,850$ \\
\hline Cyprus & 120 & 220 & 325 & 1,350 & 1,470 & 730 \\
\hline Czech Republic & - & - & - & - & 500 & 361 \\
\hline Denmark & 4,000 & 6,738 & 7,582 & 8,200 & 8,686 & 10,304 \\
\hline Estonia & - & - & - & - & 100 & 125 \\
\hline Finland & 100 & 100 & 100 & 800 & 1,465 & 1,668 \\
\hline France & 32,342 & 78,777 & $1,61,800$ & $1,98,500$ & $1,96,254$ & $1,15,669$ \\
\hline Germany & 10,530 & 26,682 & 47,794 & 56,000 & 63,000 & 62,000 \\
\hline Greece & - & - & 300 & 500 & 495 & 3,255 \\
\hline Hungary & 500 & 500 & 500 & 5,000 & 18,414 & 14,249 \\
\hline Iceland & - & - & - & - & 450 & 583 \\
\hline India & 500 & 1,000 & 1,400 & 4,000 & 23,000 & 40,600 \\
\hline Indonesia & - & - & 500 & 8,000 & 25,500 & 45,851 \\
\hline Iran, Islamic Republic of & - & - & - & 6,387 & 19,000 & 37,664 \\
\hline Ireland & 5,000 & 3,000 & 8,000 & 39,000 & 68,000 & 67,063 \\
\hline Israel & - & - & - & 1,080 & 7,500 & 10,001 \\
\hline Italy & 6,464 & 20,423 & 47,607 & 79,536 & 72,900 & $7,61,858$ \\
\hline Japan & 35,000 & 50,000 & 78,400 & 78,000 & 66,100 & 60,180 \\
\hline Jordan & - & - & - & 250 & 600 & 1,123 \\
\hline Kazakhstan & - & - & - & - & 500 & 558 \\
\hline Korea, Democratic People's Republic of & - & - & - & 5,500 & 5,932 & 5,700 \\
\hline Korea, Republic of & 100 & 10,173 & 18,910 & 8,992 & 21,251 & 30,574 \\
\hline Kyrgyzstan & - & - & - & - & 1,606 & 201 \\
\hline Latvia & - & - & - & - & 534 & 517 \\
\hline Lithuania & - & - & - & - & 2,900 & 12,700 \\
\hline Luxembourg & - & - & - & - & 15 & 5 \\
\hline Macedonia, The former Yugoslav Republic of & - & - & - & - & 2,400 & 2,784 \\
\hline Madagascar & - & - & - & 800 & 1,067 & 2,087 \\
\hline Malta & - & - & - & - & 781 & 947 \\
\hline Moldova, Republic of & - & - & - & - & 400 & 475 \\
\hline Mongolia & - & - & - & - & 12 & 278 \\
\hline Morocco & 300 & 600 & 620 & 1,500 & 1,973 & 2,045 \\
\hline Netherlands & 4,000 & 35,000 & 68,000 & $1,65,000$ & $2,75,000$ & $3,04,000$ \\
\hline New Zealand & 300 & 1,073 & 2,936 & 3,000 & 8,500 & 9,884 \\
\hline Philippines & - & - & - & 460 & 565 & 571 \\
\hline Poland & 5,087 & 4,802 & 23,000 & $1,01,500$ & $1,10,000$ & $1,98,235$ \\
\hline Portugal & - & - & - & 1,046 & 1,311 & 1,240 \\
\hline Réunion & - & - & - & 70 & 48 & 61 \\
\hline Romania & - & - & - & 5,608 & 6,000 & 7,661 \\
\hline Russian Federation & - & - & - & - & 6,000 & 4,200 \\
\hline Serbia & - & - & - & - & - & 4,851 \\
\hline Serbia and Montenegro & - & - & - & - & 13,000 & - \\
\hline Singapore & - & - & - & - & - & 101 \\
\hline Slovakia & - & - & - & - & 500 & 1,898 \\
\hline Slovenia & - & - & - & - & 1,305 & 1,060 \\
\hline South Africa & - & - & - & 4,833 & 7,019 & 12,568 \\
\hline Spain & 3,000 & 6,414 & 35,528 & 29,693 & $1,09,605$ & $1,48,000$ \\
\hline Switzerland & 1,600 & 2,900 & 4,200 & 6,374 & 7,000 & 8,524 \\
\hline Thailand & 100 & 200 & 400 & 9,404 & 9,800 & $6,, 791$ \\
\hline Tunisia & - & - & - & 70 & 79 & 122 \\
\hline Turkey & - & - & - & 1,300 & 1,100 & 2,7058 \\
\hline Ukraine & - & - & - & - & 3,400 & 14,000 \\
\hline United Kingdom & 20,000 & 50,193 & 64,600 & $1,23,300$ & 92,600 & 69,300 \\
\hline United States of America & 50,000 & $1,04,948$ & $2,12,990$ & $3,38,760$ & $3,76,980$ & $3,90,902$ \\
\hline Uzbekistan & - & - & - & - & 300 & 661 \\
\hline Viet Nam & 1,000 & 2,500 & 4,000 & 9,000 & 16,000 & 21,957 \\
\hline Yugoslav SFR & 1,300 & 4,000 & 4,400 & 3,900 & - & - \\
\hline Zimbabwe & - & - & - & 390 & 250 & 613 \\
\hline World & $4,95,127$ & $8,57,987$ & $12,57,521$ & $22,08,125$ & $45,14,588$ & $77,19,364$ \\
\hline
\end{tabular}


Table 3. World mushroom production (metric tons) of different countries and continents (1991-2011) (UNFAOSTAT 2011).

\begin{tabular}{|c|c|c|c|c|c|c|c|c|c|c|c|c|c|c|c|c|c|c|c|c|c|}
\hline Country & 1991 & 1992 & 1993 & 1994 & 1995 & 1996 & 1997 & 1998 & 1999 & 2000 & 2001 & 2002 & 2003 & 2004 & 2005 & 2006 & 2007 & 2008 & 2009 & 2010 & 2011 \\
\hline Albania & & - & - & & 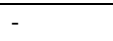 & 100 & 94 & 98 & 92 & 96 & 101 & 104 & 114 & 118 & 101 & 100 & 99 & 105 & 107 & 100 & 123 \\
\hline Algeria & 100 & 107 & 116 & 110 & 122 & 116 & 115 & 125 & 110 & 97 & 120 & 123 & 130 & 150 & 170 & 200 & 197 & 191 & 229 & 220 & 220 \\
\hline Australia & 24,394 & 25,502 & 27,575 & 38,889 & 33,337 & 34,945 & 35,485 & 38,895 & 37,568 & 36,000 & 39,394 & 43,412 & 39,288 & 46,265 & 47,992 & 43,641 & 42,739 & 47,102 & 43,416 & 41,295 & 49,696 \\
\hline Austria & 2,700 & 2,500 & 2,485 & 2,080 & 1,255 & 800 & 300 & 100 & 100 & 100 & 300 & 500 & 800 & 900 & 900 & 900 & 900 & 900 & 1,100 & 1,300 & 1,600 \\
\hline Belarus & & - & - & 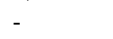 & - & - & - & 4,500 & 4,200 & 5,000 & 8,000 & 5,000 & 7,000 & 7,117 & 7,018 & 8,000 & 6,800 & 7,000 & 7,037 & 7,000 & 6,500 \\
\hline Belgium & - & - & - & - & - & - & - & - & - & 46,300 & 40,500 & 42,500 & 43,000 & 44,526 & 41,608 & 41,712 & 43,361 & 40,000 & 42,266 & 41,728 & 41,556 \\
\hline Bosnia and Herzegov & $a-$ & 300 & 263 & 400 & 300 & 400 & 700 & 800 & 900 & 1,200 & 800 & 1,000 & 829 & 1,500 & 2,000 & 1,000 & 1,000 & 956 & 943 & 1,200 & 994 \\
\hline Bulgaria & 5,200 & 4,435 & 5,000 & 9,000 & 8,000 & 12,000 & 13,000 & 11,000 & 10,200 & 11,500 & 10,000 & 8,961 & 9,341 & 11,000 & 3,000 & 1,894 & 1,716 & 1,438 & 1,725 & 1,619 & 2,171 \\
\hline Canada & 53,020 & 53,700 & 54,670 & 56,610 & 62,690 & 59,410 & 68,020 & 72,880 & 69,280 & 80,241 & 86,357 & 75,075 & 87,937 & 84,682 & 80,071 & 87,631 & 73,260 & 79,990 & 65,550 & 72,930 & 78,930 \\
\hline hina & $7,95,013$ & $8,85,254$ & $9,61,955$ & $10,89,991$ & $12,08,672$ & $13,11,027$ & $14,62,196$ & $18,95,691$ & $21,83,006$ & $24,08,234$ & $26,69,841$ & $28,59,806$ & $30,09,469$ & $33,60,513$ & $34,09,686$ & $36,84,342$ & $40,68,518$ & $47,10,574$ & $46,80,720$ & $48,33,725$ & $50,08,850$ \\
\hline Cyprus & 1,350 & 1,800 & 2,300 & 2,150 & 1,650 & 1,500 & 2,170 & 2,300 & 2,000 & 1,730 & 1,470 & 1,270 & 1,200 & 1,101 & 1,014 & 828 & 1,213 & 1,013 & 793 & 790 & 730 \\
\hline Czech R & & & 100 & 300 & 500 & 200 & 300 & 100 & 200 & 1,000 & 500 & 800 & 800 & 150 & 350 & 250 & 313 & 400 & 311 & 261 & 361 \\
\hline Korea & 5,500 & 4,500 & 4,370 & 4,800 & 4,000 & 4,252 & 4,319 & 5,000 & 6,000 & 5,867 & 5,932 & 200 & 6,263 & 6,300 & 6,262 & 6,000 & 6,500 & 6,377 & 6,335 & 6,540 & 5,700 \\
\hline nmark & 8,200 & 9,371 & 9,000 & 8,391 & 10,000 & 10,000 & 8,766 & 8,314 & 8,300 & 8,686 & 8,686 & 8,686 & 8,180 & 946 & 10,946 & 10,946 & 11,000 & 10,000 & 9,500 & 9,541 & 10,304 \\
\hline nland & 8 & 1,150 & 1,155 & 1,107 & 1,171 & 1,443 & 1,242 & 1,364 & 1,623 & & 1,465 & 1, & 2 & 30 & 1,996 & 2,054 & 2,016 & & 1,812 & 1,645 & 1,668 \\
\hline ance & $1,98,500$ & $1,96,600$ & $1,84,039$ & $1,71,692$ & $1,64,154$ & $1,89,213$ & $1,73,000$ & $1,51,564$ & $1,51,889$ & 811 & $1,96,254$ & $1,75,288$ & $1,65,647$ & $1,65,466$ &, 541 & $1,15,846$ & $1,62,450$ & & $1,13,851$ & $1,19,346$ & $1,15,669$ \\
\hline erman & 5600 & 60,000 & 58,000 & 58,000 & 57,000 & 59,000 & 60,000 & 60,00 & 60,000 & 62,00 & 63,000 & 62,000 & 50 & 50,000 & 50 & 59,000 & 55,000 & & 52,200 & 60,000 & 62,000 \\
\hline reece & 500 & 454 & 476 & 485 & 482 & 492 & 485 & 504 & 1,200 & 500 & 495 & 500 & 2,500 & 2,516 & 2,262 & 2,474 & 3,500 & 3,334 & 3,565 & 3,181 & 3,255 \\
\hline & 5,000 & 5,904 & 6,916 & 6,802 & 7,651 & 10,76 & 13,55 & 14,42 & 15,901 & 16,926 & 1 &, 25 & 22,396 & 303 & 19,734 & 21,208 & 21,637 & 906 & 21,950 & 14,026 & 14,249 \\
\hline Me & - & 21 & 22 & 2 & 25 & 25 & 29 & 3 & 37 & 4. & 4 & 45 & 465 & 4 & 4 & & 5 & & 553 & 579 & 583 \\
\hline lia & 4,00 & 10 & 1 & 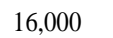 & & 16,000 & 9, & 13,500 & 14,000 & 00 & & 40,000 & 00 & 40 & 40,000 & 00 & 37,000 & 000 & 37,000 & 40,600 & 40,600 \\
\hline Indones & & 21 & 19 & & & 22 , & & 8, & 24, & & & & & & & & 48 & & 38 & & 45,851 \\
\hline & & & 7, & & & 9 & & & & & & & & & & & & & & & 564 \\
\hline lan & 000 & 40,700 & 45,00 & 49,000 & 49,00 & 54,000 & & 62,000 & 64,800 & 59,800 & 68,000 & 69,000 & 69,000 & 65,000 & 62,000 & 75,000 & 81,000 & 90,000 & 60,000 & 65,000 & 67,063 \\
\hline . & 1,080 & 1,032 & 1,010 & 1,040 & 860 & 1,160 & 1,260 & 1,000 & 1,000 & 7,500 & 7,500 & 7,800 & 8,600 & 9,000 & & 9,500 & 9,500 & & 9,500 & 9,500 & 10,001 \\
\hline & & & 67 & & & & & & & & & & & & & & & 000 & $7,20,100$ & 000 & $7,61,858$ \\
\hline Ja & 78,000 & 76,800 & 77,40 & 74,300 & 74,495 & 75,157 & 74,78 & 74,217 & 70,511 & 67,224 & 66,10 & 64,400 & 65,400 & 66,200 & 66,000 & 65,000 & 67,000 & 67,500 & 63,084 & 59,550 & 60,180 \\
\hline Jordan & 250 & 500 & 355 & 450 & 500 & 500 & 500 & 750 & 600 & 500 & 60 & 700 & 675 & 764 & 795 & 832 & 852 & & 910 & 1,030 & 1,123 \\
\hline$\Delta$ & - & 5 & 5 & 5 & 6 & 73 & $9 ?$ & 1, & 1,397 & & 1 & 1 , & 3 & 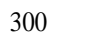 & 2 & & 2 & & 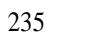 & 200 & 201 \\
\hline & - & 20 & & & 5 & 4 & 3 & & & 5 & & & & & & & & & & & \\
\hline L & - & 2,0 & 3,0 & 2,0 & 3, & 2,5 & 2,3 & 5 , & 2, & 6 & 2 & , & 2 & 3,87 & 4,0 & 5,1 & 6,6 & 8,1 & 14,056 & 10,400 & 12,700 \\
\hline Luxen & - & - & - & - & - & - & - & 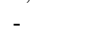 & - & 16 & 1 & 15 & 1 & 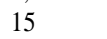 & & 5 & 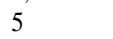 & 5 & & 5 & 5 \\
\hline adao & 80 & 88 & 796 & 86 & 1,0 & 1,0 & 1,1 & 1 & 1, & 1,0 & 100 & 10 & 1,2 & & 1 & 1 & 1 & 1,5 & 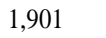 & 22 & 2,087 \\
\hline $\mathrm{N}$ & - & - & - & - & - & - & - & 900 & 863 & 849 & 7 & 644 & 6 & 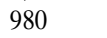 & 98 & 95 & 1,093 & 1,130 & 1,188 & 1,088 & 947 \\
\hline & - & - & - & - & - & 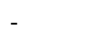 & - & 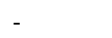 & - & 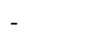 & 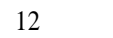 & 2 & & & & & & & & 235 & \\
\hline Moro & 1, & 1,7 & 1,6 & 1,7 & 1,2 & 1,7 & 1, & & 1,6 & & & & & & & & 1, & & & 1,943 & 2,045 \\
\hline & $1,65,000$ & $1,90,000$ & $1,90,000$ & $2,20,000$ & $2,30,000$ & $2,37,000$ & $2,40,000$ & $2,46,000$ & $2,50,000$ & $2,65,000$ & $2,75,000$ & $2,70,000$ & $2,63,000$ & $2,60,000$ & $2,45,000$ & 000 & $2,40,000$ & $2,55,000$ & $2,30,000$ & $2,66,000$ & $3,04,000$ \\
\hline & 100 & 3,500 & 4,300 & 6000 & 5500 & 6,300 & 7500 & 8,400 & 8,150 & 8,500 & 850 & 8,500 & & 880 & 8,600 & & 8,500 & 9,368 & 8,635 & 8,213 & 9,884 \\
\hline Philippines & 460 & 455 & 501 & 482 & 481 & 737 & 762 & 56 & 563 & 569 & 565 & 560 & 570 & 54 & 508 & 551 & 565 & 564 & 557 & 526 & 571 \\
\hline 1 & 1,01 , & 1,00 , & 1,18 & 1,03 , & 1,14 , & 1,04 & 1,01 , & $1,02,570$ & 1,06 , & $1,13,479$ & 1,10, & $1,20,000$ & 1,30 , & $1,50,000$ & 1,60 & 1,53 & 1,80 & 000 & $1,99,148$ & $1,73,448$ & 1,98 \\
\hline Portugal & 1,046 & 854 & 1,060 & 1,151 & 1,175 & 1,275 & 1,160 & 1,448 & 1,430 & 1,251 & 1,311 & 1,143 & 1,173 & & 1,423 & 1,289 & 1,050 & 1,070 & 1,100 & 1,400 & 1,240 \\
\hline Republi & 8,992 & 10,00 & 11,183 & 10,037 & 9,582 & 12,418 & 13,181 & 16,000 & 19,774 & 20,659 & 21,251 & 24,688 & 24,957 & 27,781 & 28,375 & 27,404 & 28,764 & 28,361 & 27,033 & 26,250 & 30,574 \\
\hline Rep & , & 50 & 400 & 307 & 314 & 20 & 19 & 50 & 498 & 30 & 40 & & 355 & 300 & 400 & 450 & 400 & 438 & 499 & 463 & 475 \\
\hline Réuni & 70 & 79 & 82 & 88 & 8 & 8 & 7 & 6 & 5 & 6 & 4 & & 4 & & 5 & 49 & 43 & 5 & 56 & 6 & 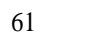 \\
\hline & 5,60 & & & & & & & & & & & & & & & & & & & 00 & 76 \\
\hline ederation & - & 200 & 400 & 750 & 1 , & 1,500 & 1, & 3,500 & 3,600 & 6,000 & 6,000 & 7,000 & 5,700 & 6,000 & 5,000 & 6,000 & 5,700 & 6,000 & 6,200 & 5,500 & 4,200 \\
\hline negro & & 3,000 & 1,500 & 2,000 & & 7,000 & 8,000 & 8,325 & 10,000 & & 13,00 & & 13,163 & & & & & & & & \\
\hline Slovakia & & & 600 & 700 & 700 & 800 & 700 & 600 & 800 & 600 & 900 & 800 & 900 & 1,000 & 1,100 & 1,300 & 1,500 & 1,800 & 2,000 & 2,335 & 1,898 \\
\hline
\end{tabular}




\begin{tabular}{|c|c|c|c|c|c|c|c|c|c|c|c|c|c|c|c|c|c|c|c|c|c|}
\hline Slovenia & & 1,500 & 1,732 & 1,621 & 1,786 & 1,881 & 1,833 & 1,701 & 1,970 & 1,683 & 1,305 & 1,505 & 1,376 & 1,100 & 1,200 & 1,080 & 894 & 1,043 & 1,150 & 823 & 1,060 \\
\hline South Africa & 4,833 & 4,142 & 4,735 & 6,200 & 7,824 & 7,048 & 7,406 & 6,507 & 7,617 & 7,278 & 7,019 & 7,021 & 8,610 & 8,415 & 8,385 & 8,477 & 10,320 & 11,351 & 11,744 & 12,217 & 12,568 \\
\hline Spain & 29,693 & 67,077 & 67,116 & 70,814 & 75,968 & 71,529 & 81,304 & 80,000 & 93,600 & 63,254 & $1,09,605$ & $1,34,669$ & $1,29,205$ & $1,38,782$ & $1,37,764$ & $1,35,419$ & $1,31,974$ & $1,33,548$ & $1,31,000$ & $1,33,000$ & $1,48,000$ \\
\hline Switzerland & 6,374 & 7,365 & 7,300 & 7,614 & 8,083 & 7,666 & 7,239 & 7,800 & 7,100 & 7,350 & 7,000 & 7,400 & 6,800 & 7,451 & 7,440 & 7,440 & 7,440 & 7,500 & 7,905 & 8,465 & 8,524 \\
\hline Thailand & 9,404 & 8,161 & 9,000 & 10,838 & 9,200 & 9,168 & 9,000 & 9,200 & 9,455 & 9,500 & 9,800 & 9,035 & 8,503 & 10,000 & 9,123 & 6,964 & 6,394 & 6,366 & 6,933 & 6,925 & 6,791 \\
\hline Macedonia & - & 3,000 & 1,500 & 1,596 & 2,000 & 1,900 & 1,600 & 1,836 & 1,800 & 2,000 & 2,400 & 3,000 & 2,000 & 2,500 & 3,000 & 3,166 & 2,500 & 2,606 & 2,870 & 2,900 & 2,784 \\
\hline Tunisia & 70 & 71 & 60 & 62 & 57 & 73 & 67 & 75 & 69 & 72 & 79 & 88 & 96 & 103 & 99 & 100 & 107 & 114 & 120 & 126 & 122 \\
\hline Turkey & 1,30 & 1,000 & 964 & 1,022 & 1,13 & 2,00 & 1,200 & 3,000 & 5,000 & 7,000 & 9,000 & 11,000 & 13,000 & 15,000 & 17,000 & 21,833 & 23,426 & 26,526 & 19,501 & 21,559 & 27,058 \\
\hline Ukraine & . & - & 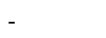 & - & - & - & 2,000 & 2,500 & 3,000 & 3,500 & 3,400 & 3,500 & 4,000 & 5,000 & 6,000 & 8,500 & 7,200 & 6,300 & 8,500 & 11,000 & 14,000 \\
\hline UK & $1,23,300$ & $1,20,613$ & $1,22,327$ & $1,33,842$ & $1,01,671$ & $1,06,555$ & $1,07,359$ & $1,09,500$ & $1,04,700$ & 89,900 & 92,600 & 84,700 & 81,00 & 74, & 74,000 & 68,000 & & & 69,400 & 69,300 & 69,300 \\
\hline USA & $3,38,760$ & $3,52,150$ & $3,40,560$ & $3,54,250$ & $3,52,836$ & $3,52,300$ & $3,66,810$ & $3,84,540$ & $3,87,550$ & $3,83,830$ & $3,76,980$ & $3,77,080$ & $3,87,601$ & $3,87,601$ & $3,86,984$ & $3,82,541$ & $3,59,630$ & $3,68,591$ & $3,71,844$ & $3,59,469$ & $3,90,902$ \\
\hline Uzbekistan & & 300 & 251 & 244 & 220 & 204 & 400 & 500 & 400 & 387 & 300 & 316 & 359 & 360 & 382 & 464 & 509 & 573 & 626 & 600 & 661 \\
\hline Viet Nam & 000 & 9,500 & 10,000 & 10,500 & 11,443 & 10,000 & 10,339 & 12,000 & 14,000 & 20,500 & 16,000 & 16,299 & 16,819 & 18,000 & 18,229 & 18,646 & 18,818 & 19,514 & 20,808 & 21,213 & 21,957 \\
\hline Zim & & 433 & 388 & 424 & 406 & 411 & 426 & 220 & 24 & 230 & 250 & 320 & 380 & 396 & 350 & 438 & 484 & 467 & 558 & & 613 \\
\hline European Union & $8,43,525$ & $9,19,219$ & $9,16,872$ & $9,42,900$ & $9,30,626$ & $9,67,656$ & $9,62,173$ & $9,68,922$ & $9,89,890$ & $10,34,113$ & $10,83,035$ & $10,90,194$ & $10,81,820$ & $11,05,509$ & $10,47,441$ & $10,37,256$ & $11,06,404$ & $12,61,019$ & $16,86,197$ & $17,86,777$ & $18,28,172$ \\
\hline World & 08,125 & $24,14,029$ & $24,80,950$ & $26,74,641$ & $27,78,923$ & $29,24,672$ & $30,88,289$ & $35,65,119$ & $38,98,091$ & $42,09,014$ & $45,29,888$ & $47,30,468$ & $49,06,897$ & $52,78,753$ & $52,91,401$ & $55,43,719$ & $59,88,612$ & $68,01,565$ & $71,73,819$ & $74,50,29$ & $77,19,364$ \\
\hline Africa & 763 & 7,420 & 7,777 & 9,453 & 10,867 & 10,441 & 10,846 & 9,905 & 10,971 & 10,538 & 10,556 & 10,494 & 12,522 & 12,323 & 11,938 & 12,834 & 14,680 & 15,651 & 16,495 & 17,439 & 17,716 \\
\hline Amer & 1,78 & $4,05,850$ & $3,95,230$ & $4,10,860$ & $4,15,526$ & $4,11,710$ & $4,34,830$ & $4,57,420$ & $4,56,830$ & $4,64,071$ & $4,63,337$ & $4,52,155$ & $4,75,538$ & $4,72,283$ & $4,67,055$ & $4,70,172$ & $4,32,890$ & $4,48,581$ & $4,37,394$ & $4,32,399$ & $4,69,832$ \\
\hline Asia & 28,739 & $10,38,763$ & $11,18,412$ & $12,54,602$ & $13,69,969$ & $14,76,088$ & $16,18,006$ & $20,53,641$ & $23,65,113$ & $26,19,629$ & $28,84,985$ & $30,83,575$ & $32,50,003$ & $35,92,187$ & $36,66,571$ & $39,30,858$ & $43,47,798$ & $49,83,826$ & $49,42,145$ & $51,22,15$ & $53,01,160$ \\
\hline Euro & 2,449 & $9,32,994$ & $9,27,656$ & $9,54,837$ & $9,43,724$ & $9,85,188$ & $9,81,622$ & $9,96,858$ & $10,19,459$ & $10,70,276$ & $11,23,116$ & $11,32,332$ & $11,21,046$ & $11,46,855$ & $10,89,245$ & $10,76,172$ & $11,42,005$ & $12,97,037$ & $17,25,734$ & $18,28,79$ & $18,71,076$ \\
\hline Australia & 27,394 & 29,002 & 31,875 & 44,889 & 38,837 & 41,245 & 42,985 & 47,295 & 45,718 & 44,500 & 47,894 & 51,912 & 47,788 & 55,105 & 56,592 & 53,683 & 51,239 & 56,470 & 52,051 & 49,508 & 59,580 \\
\hline
\end{tabular}


The mushroom industry is based on two aspects which complement each other (sometimes called two legs of the mushroom industry) viz. mushroom science concerned with mushroom production and mushroom biotechnology concerned mushroom products. In the past, the focus was mainly on the production of fresh, canned and dried mushrooms. This means the industry had only one leg thus can't go long way in most efficacious manner, but at present, the focus on second leg has strengthened the mushroom industry to establish and spread its roots

The paradigm shift resulted generation of large income from mushroom products, e.g. in 1987, the value of pharmaceuticals developed from three mushrooms: Coriolus versicolor, Lentinula edodes and Schizophyllum commune was reported to be 769 million dollars annually in Japan alone (Chang and Buswell 1993). There are several other mushroom products e.g. those from Ganoderma manufactured and used in China, Korea and Taiwan that are also worthy many millions of dollars. Table 7. evinces the income generated by Japan and USA by the sale of raw anticancer drugs as early as 1987. The monetary returns from medicinal mushrooms and their derivative dietary supplements worldwide was estimated about US\$1.2 billion in 1991, US\$3.6 billion in 1994 and US\$6.0 billion in 1999 (Chang 1996; Wasser et al. 2000). In 2001, the figure of US\$9-10 billion was cited as representing the value of medicinal mushroom products, including tonics and medicines. The market value of Ganoderma-based nutriceuticals alone in 1995 was estimated US\$1.6 billion (Chang and Buswell 1999). A lot of mushrooms are traded in china for diverse medicinal uses (Wasser 2010). The corresponding monetary values will touch new heights if the medicinal potential of other medicinal mushrooms is fully exploited.

\section{International efforts to publicize the science}

The mushroom industry seems to be one of the fastest growing investment sectors in the world, yet lot is to be done to watch full phase of the moon. Prior to practice the practice it is important to know how and to what extent the benefits of both mushroom production and mushroom products can be maximized. We need to increase mushroom production through the improvement of mushroom biotechnology and make greater leaps and advancements in the mushroom industry which in turn contribute more to the welfare in mankind. To achieve the goals of mushroom industry it is essential that there is cooperation in the exchange of information and technology concerning mushroom production and mushroom products among research scientists, industry, regulatory agencies, government and the public.

Theoretically three segments could be identified in mushroom industry with each received international recognition as important inter-related components and

Table 4. The US mushroom industry is dominated by Agaricus bisporus (NASS 2005).

\begin{tabular}{lccc}
\hline Mushroom production (t) & $\mathbf{2 0 0 2 - 2 0 0 3}$ & $\mathbf{2 0 0 3 - 2 0 0 4}$ & $\mathbf{2 0 0 4 - 2 0 0 5}$ \\
\hline Agaricus & 379318.8 & 381479.4 & 380083.0 \\
& $(98.6 \%)$ & $(98.4 \%)$ & $(98.2 \%)$ \\
Lentinula & 3390.5 & 3506.1 & 4118.4 \\
& $(0.9 \%)$ & $(0.9 \%)$ & $(1.1 \%)$ \\
Pleurotus & 1812.6 & 2008.2 & 2453.0 \\
& $(0.5 \%)$ & $(0.5 \%)$ & $(0.6 \%)$ \\
Sub-total & 384521.9 & 386993.7 & 386654.4 \\
& $(99.9 \%)$ & $(99.9 \%)$ & $(99.9 \%)$ \\
Others & $197.3 \% 341.0$ & $(0.01 \%)$ \\
& $(0.01 \%)$ & $(0.01 \%)$ & 386907.9 \\
Grand total & 384719.2 & 387534.7 & $(100 \%)$ \\
\hline
\end{tabular}

Table 5. Asia's mushroom industry is more diverse (2003 data) (Chang 2006; Cui 2004; Ho and Peng 2006).

\begin{tabular}{|c|c|c|c|c|}
\hline Production & China (x1000t) & Japan (t) & S. Korea (t) & Taiwan (t) \\
\hline Agaricus & $\begin{array}{c}1330.4 \\
(12.8 \%)\end{array}$ & - & $\begin{array}{l}19790 \\
(11.6 \%)\end{array}$ & $\begin{array}{l}4276 \\
(4.0 \%)\end{array}$ \\
\hline Lentinula & $\begin{array}{l}2228 \\
(21.5 \%)\end{array}$ & $\begin{array}{l}35294 \\
(10.7 \%)\end{array}$ & $\begin{array}{l}41876 \\
(24.6 \%)\end{array}$ & $\begin{array}{l}36000 \\
(33.4 \%)\end{array}$ \\
\hline Pleurotus & $\begin{array}{l}2488 \\
(24.0 \%)\end{array}$ & $\begin{array}{l}5219 \\
(1.6 \%)\end{array}$ & $\begin{array}{l}61965 \\
(36.5 \%)\end{array}$ & $\begin{array}{l}4540 \\
(4.2 \%)\end{array}$ \\
\hline Sub-total & $\begin{array}{l}6046.4 \\
(58.2 \%)\end{array}$ & $\begin{array}{l}40513 \\
(12.3 \%)\end{array}$ & $\begin{array}{l}123631 \\
(72.7 \%)\end{array}$ & $\begin{array}{l}44816 \\
(41.6 \%)\end{array}$ \\
\hline Others & $\begin{array}{c}4340.5 \\
(41.8 \%)\end{array}$ & $\begin{array}{c}290333 \\
(87.8 \%)\end{array}$ & $\begin{array}{l}46369 \\
(27.3 \%)\end{array}$ & $\begin{array}{l}62984 \\
(58.4 \%)\end{array}$ \\
\hline Grand total & $\begin{array}{r}10386.9 \\
(100 \%) \\
\end{array}$ & $\begin{array}{c}330846 \\
(100 \%) \\
\end{array}$ & $\begin{array}{c}170000 \\
(100 \%) \\
\end{array}$ & $\begin{array}{c}107800 \\
(100 \%)\end{array}$ \\
\hline
\end{tabular}


Table 6. Gross Production Value of mushrooms in current million US\$) (USD) from 1991-2011 (UNFAOSTAT 2011).

\begin{tabular}{|c|c|c|c|c|c|c|c|c|c|c|c|c|c|c|c|c|c|c|c|c|c|}
\hline Country & 1991 & 1992 & 1993 & 1994 & 1995 & 1996 & 1997 & 1998 & 1999 & 2000 & 2001 & 2002 & 2003 & 2004 & 2005 & 2006 & 2007 & 2008 & 2009 & 2010 & 2011 \\
\hline Australia & 74 & 72 & 72 & 113 & 94 & 102 & 100 & 98 & 97 & 86 & 93 & 109 & 125 & 162 & 185 & 184 & 218 & 236 & 198 & 216 & 302 \\
\hline Canada & 131 & 122 & 118 & 124 & 140 & 131 & 151 & 152 & 143 & 174 & 177 & 164 & 209 & 218 & 226 & 255 & 230 & 252 & 197 & 240 & 282 \\
\hline China & 702 & 1749 & 2195 & 1323 & 1386 & 3448 & 3386 & 4417 & 3697 & 3790 & 3287 & 4971 & 4944 & 5844 & 6199 & 7362 & 9282 & 11885 & 9218 & 3013 & 6160 \\
\hline Denmark & 20 & 23 & 20 & 19 & 26 & 24 & 18 & 19 & 18 & 26 & 24 & 26 & 24 & 35 & 36 & 34 & 30 & 36 & 39 & 37 & 47 \\
\hline France & 235 & 261 & 236 & 239 & 269 & 217 & 165 & 139 & 135 & 159 & 144 & 131 & 146 & 159 & 147 & 112 & 174 & 35 & 138 & 144 & 156 \\
\hline Germany & 121 & 134 & 108 & 110 & 131 & 130 & 120 & 122 & 82 & 85 & 119 & 101 & 124 & 129 & 116 & 152 & 154 & 149 & 139 & 151 & 153 \\
\hline India & 4 & 6 & 7 & 14 & 12 & 13 & 7 & 14 & 17 & 17 & 20 & 31 & 31 & 33 & 36 & 32 & 40 & 41 & 41 & 46 & 47 \\
\hline Indonesia & 5 & 12 & 11 & 16 & 14 & 14 & 11 & 2 & 25 & 24 & 26 & 19 & 36 & 10 & 36 & 33 & 73 & 103 & 97 & 188 & 186 \\
\hline Iran & 64 & 152 & 6 & 5 & 9 & 8 & 15 & 26 & 14 & 28 & 50 & 13 & 14 & 25 & 30 & 32 & 34 & 60 & 33 & 61 & 96 \\
\hline Ireland & 89 & 98 & 94 & 105 & 124 & 151 & 154 & 156 & 153 & 124 & 137 & 153 & 177 & 189 & 179 & 218 & 295 & 374 & 230 & 158 & 172 \\
\hline Israel & & 6 & 5 & 5 & 4 & 4 & 5 & 3 & 3 & 31 & 21 & 20 & 25 & 26 & 28 & 28 & 31 & 35 & 32 & 34 & 72 \\
\hline Italy & 174 & 198 & 123 & 121 & 114 & 123 & 101 & 103 & 107 & 110 & 103 & 121 & 190 & 205 & 196 & 220 & 212 & 948 & 1930 & 1979 & 2006 \\
\hline Japan & 326 & 199 & 510 & 400 & 385 & 228 & 288 & 408 & 315 & 226 & 231 & 193 & 250 & 301 & 286 & 248 & 242 & 307 & 316 & 361 & 381 \\
\hline Net & 225 & 252 & 250 & 311 & 334 & 325 & 296 & 310 & 309 & 305 & 394 & 384 & 414 & 440 & 385 & 378 & 449 & 500 & 374 & 427 & 517 \\
\hline Nev & 8 & 8 & 9 & 14 & 13 & 15 & 17 & 16 & 15 & 14 & 13 & 14 & 18 & 21 & 22 & 25 & 26 & 28 & 24 & 27 & 37 \\
\hline Polar & 96 & 95 & 124 & 105 & 113 & 102 & 93 & 89 & 81 & 86 & 8 & 9 & 110 & 153 & 180 & 179 & 250 & 293 & 273 & 236 & 289 \\
\hline Republic of Korea & 20 & 29 & 39 & 31 & 29 & 46 & 43 & 29 & 38 & 60 & 5 & 60 & 52 & 52 & 49 & 91 & 101 & 78 & 61 & 73 & 94 \\
\hline South Africa & 13 & 12 & 12 & 15 & 18 & 16 & 15 & 10 & 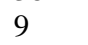 & 11 & 11 & 13 & 18 & 25 & 22 & 22 & 14 & 22 & 14 & 14 & 27 \\
\hline Spain & 33 & 81 & 64 & 68 & 83 & 74 & 78 & 79 & 92 & 56 & 96 & 112 & 130 & 182 & 202 & 193 & 207 & 227 & 166 & 170 & 213 \\
\hline Switzerland & 34 & 34 & 33 & 40 & 53 & 40 & 42 & 35 & 35 & 38 & 29 & 40 & 42 & 49 & 46 & 50 & 51 & 56 & 55 & 78 & 80 \\
\hline Turkey & 2 & 1 & 1 & 1 & 2 & 2 & 1 & 5 & 6 & 10 & 8 & 10 & 18 & 25 & 31 & 42 & 54 & 69 & 42 & 56 & 61 \\
\hline United Kingdom & 314 & 284 & 270 & 296 & 240 & 271 & 483 & 251 & 232 & 196 & 181 & 187 & 203 & 190 & 171 & 162 & 159 & 152 & 115 & 129 & 119 \\
\hline United States of America & 646 & 679 & 647 & 715 & 727 & 726 & 760 & 856 & 855 & 855 & 889 & 873 & 906 & 923 & 913 & 886 & 920 & 959 & 959 & 927 & 1022 \\
\hline Wor & 3423 & 4 & 5 & 20 & 4 & 34 & 6488 & 7 & & 6 & 6364 & 23 & 8413 & 9612 & 9931 & 11152 & 1350 & 119 & 14982 & 9061 & 12809 \\
\hline Africa $+($ Total $)$ & 17 & 17 & 17 & 18 & 22 & 20 & 19 & 14 & 13 & 15 & 14 & 16 & 23 & 28 & 26 & 26 & 19 & 28 & 21 & 21 & 34 \\
\hline Americas + (Total $)$ & 777 & 802 & 765 & 839 & 867 & 857 & 911 & 1009 & 998 & 1029 & 1066 & 1037 & 1115 & 1141 & 1139 & 1140 & 1150 & 1211 & 1156 & 1167 & 1304 \\
\hline Northern America + (Total) & 777 & 802 & 765 & 839 & 867 & 857 & 911 & 1009 & 998 & 1029 & 1066 & 1037 & 1115 & 1141 & 1139 & 1140 & 1150 & 1211 & 1156 & 1167 & 1304 \\
\hline Asia + (Total) & 1127 & 2148 & 2769 & 1813 & 1856 & 3759 & 3750 & 4903 & 4122 & 4191 & 3706 & 5315 & 5370 & 6317 & 6694 & 7865 & 9857 & 12578 & 9843 & 3845 & 7108 \\
\hline Europe + (Total) & 1420 & 1544 & 1414 & 1522 & 1610 & 1581 & 1691 & 1461 & 1402 & 1329 & 1471 & 1531 & 1763 & 1944 & 1866 & 1911 & 2237 & 3038 & 3740 & 3785 & 4023 \\
\hline -Australia \& New Zealand + (Total) & 82 & 79 & 82 & 127 & 107 & 117 & 118 & 114 & 112 & 99 & 105 & 124 & 142 & 182 & 207 & 209 & 243 & 264 & 222 & 243 & 340 \\
\hline
\end{tabular}


Table 7. The top ten best selling anticancer drugs in Japan and the USA, 1987 (Fukushima 1989).

\begin{tabular}{|c|c|c|c|c|c|c|}
\hline \multicolumn{4}{|c|}{ Japan } & \multicolumn{3}{|c|}{ USA } \\
\hline & Drug & $\begin{array}{c}\text { Sales } \\
\left(\$ \times 10^{6}\right)\end{array}$ & $\begin{array}{c}\text { Market } \\
\text { share }(\%)\end{array}$ & Drug & $\begin{array}{c}\text { Sales } \\
\left(\$ \times 10^{6}\right)\end{array}$ & $\begin{array}{c}\text { Market share } \\
(\%)\end{array}$ \\
\hline 1 & PS-K & 358 & 25.2 & Doxorubicin & 86 & 16.3 \\
\hline 2 & $\mathrm{OK}-432$ & 191 & 13.4 & Cisplatin & 79 & 15.0 \\
\hline 3 & Tegafur uracil & 177 & 12.5 & Tamoxifen citrate & 68 & 12.9 \\
\hline 4 & 5-Fluorouracil & 104 & 7.3 & Etoposide & 52 & 9.8 \\
\hline 5 & Tegafur & 101 & 7.1 & Cyclophosphamide & 31 & 5.9 \\
\hline 6 & Tamoxifen citrate & 63 & 4.4 & Methotrexate & 29 & 5.5 \\
\hline 7 & Interferon $\beta$ & 40 & 2.8 & Megestrolacetate & 27 & 5.1 \\
\hline 8 & Lentinan & 31 & 2.2 & Mitomycin C & 25 & 4.7 \\
\hline 9 & Carmofur & 26 & 1.9 & Bleomycin & 20 & 3.8 \\
\hline 10 & Estramustine phosphate sodium & 25 & 1.8 & Vincristine sulphate & 18 & 3.4 \\
\hline
\end{tabular}

deserving its own special patronage and paths of development: (i) cultivated edible mushrooms (mushroom themselves-used directly or indirectly as food); (ii) medicinal mushrooms (mushroom derivatives-used as nutriceutical therapy/dietary supplements); and (iii) wild mushrooms including edible mycorrhizal, symbiotic and poisonous mushrooms (collected, up to now, only from the wild). The three International forums/bodies were developed to boost the mushroom industry all over the world (Chang et al. 1993; Chang 2006): (i) The international movement for edible mushrooms, (ii) The international movement for medicinal mushrooms, (iii) The international movement for wild mushrooms, mainly concerned with edible mycorrhizal mushrooms

\section{CONCLUDING REMARKS}

Outrightly, it is now evident and accepted fact that mushroom farming, based on applied scientific and practical knowledge using industrial or lignocellulosic waste materials available in abundance in both developed and developing countries can have positive global impact on long term food production, health, environmental conservation, regeneration of healthy environment, and socio-economic aspects of people all over the world thereby can lead to sustained agriculture and ecosystems. The biggest problem faced by the growing population of world is food scarcity, rising prices, new diseases and finally overexploitation of natural capital and dragon of pollution. In this scenario mushrooms offer a solution to almost every problem of mankind if properly and thoroughly scanned for their hidden potential and properties, thereby mushrooms auspicate non green revolution in the form of food, medicine and healthy environment.

\section{REFERENCES}

Agrahar MD, Subbulakshmi G. 2004. Nutritional value of edible wild mushrooms collected from the Khasi hills of Meghalaya. Food Chem 89 (4): 599-603.

Ayaz FA, Torun H, Ozel A, Col M, Duran C, Sesli E, Colak A. 2011. Nutritional value of some wild edible mushrooms from Black Sea region (Turkey).Turk Biyokimya Dergisi 36 (3): 213-221.
Bampus JA, Aust SD. 1987. Biodegradation of environmental pollutants by the white rot fungus, Phanerochaeta chrysosporium: Involvement of the lignin degrading system. Bio Essays 6: 166-170.

Barrosa L, Bapista P, Correria DM, Casal S, Ferrira C. 2007. Fatty acids, sugar compositions and nutritional value of five wild edible mushrooms from north east Portugal. Food Chem 105 (1): 140-145

Bernas E, Jaworska G, lisiewska Z. 2006. Edible mushrooms as a source of valuable nutritive constituents. Acta Sci Pol Technol Aliment 5(1): 5-20.

Beyer D. 2005. Spent mushroom substrate (SMS) research in the US. Amer Med Group Assoc J, Summer Issue: 31-32.

Boda RH. 2009. Studies on the mushroom flora of western Kashmir. [Ph.D. Dissertation]. Department of Botany, University of Kashmir, India.

Camargo MR, Kaneno R. 2011. Antitumor properties of Ganoderma lucidum polysaccharides and terpenoids. Ann Rev Biomed Sci 13: 18.

Chang ST, Buswell JA, Miles PG. 1993. Genetics and Breedings of Edible Mushrooms. Gordon and Breach Science Publisher, Philadelphia. USA.

Chang ST, Buswell JA. 1999. Ganoderma lucidum (Curt.: Fr.) P. Karst. (Aphyllophoromycetidease): a mushrooming medicinal mushroom. Int J Med Mush 1: 139-146.

Chang ST, Buswell JA. 2003. Medicinal mushrooms-a prominent source of nutriceuticals for the 21st century. Curr Top Nutraceut Res 1: 257 280.

Chang ST, Buswell JA. 2008. Safety, quality, control and regulational aspects relating to mushroom nutriceuticals. Proc. 6th Intl. Conf. Mushroom Biology and Mushroom Products. GAMU Gmbh, Krefeld, Germany.

Chang ST, Miles PG. 1992. Mushroom biology-a new decipline. Mycologist 6: 64-65.

Chang ST, Miles PG. 2004. Mushrooms: Cultivation, Nutritional Value, Medicinal Effect, and Environmental Impact (2nd ed). CRC Press, New York.

Chang ST. 1996. Mushroom research and development-equality and mutual benefit. In: Royse DJ (ed). Mushroom Biology and Mushroom Products. Penn. State Univ., University Park, Pennsylvania.

Chang ST. 1998. Development of novel agroscience industries based on bioconversion technology. In: Chou $\mathrm{CH}$, Shao KT (ed). Frontiers in Biology: the Challenges of Biodiversity. Academia Sinica, Taipei.

Chang ST. 2006. The world mushroom industry: trends and technological development. Inter J Med Mushr 8 (4): 297-314.

Chang, ST, Buswell JA. 1996. Mushroom nutriceuticals. World J Microbiol Biotechnol 12: 473-476.

Crisan EW, Sands A. 1978. A Nutritional value. In: Chang ST, Hayes WA (eds). The Biology and Cultivation of Edible Mushrooms. Academic Press, New York.

Cui ZH. 2004. The production, import and export of edible mushrooms in S. Korea. The Proceedings of The Coordinative Forum on the Development of Chinese Mushroom Industry, November 2004, Zhejiang, China.

Das N. 2005. Heavy metal biosorption by mushrooms-Review Article. Nat Prod Rad 4 (6): 454-459. 
Dell, B. 2002. Role of mycorrhizal fungi in ecosystems. CMU J 1 (1): 4760

Directorate of Musroom research .2011. Vission 2030, Indian Council of Agricultural Research, Chambaghat, Solan-173 213, H.P., India.

Fletcher JT, Gaze RH. 2008. Mushroom Pest and Disease Control, A Colour Handbook. Manson Publishing, Boston.

Fomina MA, Alexander IJ, Colpaert JV, Gadd GM. 2005. Solubilization of toxic metal minerals and metal tolerance of mycorrhizal fungi. Soil Biol Biochem 37: 851-866.

Fukushima M. 1989. The overdose of drugs in Japan. Nature 342: 850851.

Hawksworth DL. 2001. The magnitude of fungal diversity: the 1,5 million species estimate revisited. Mycol Res 105: 1422-1432

Ho MS, Peng JT. 2006. Edible mushroom production in Taiwan. Mushroom International (ISMS Newsletter) April Issue: 6-7.

Israilides C, Kletsas D, Arapoglou D, Philippoussis A, Pratsinis $\mathrm{H}$, Ebringerova A, Hribalova V, Harding SE. 2008. In vitro cytostatic and immunomodulatory properties of the medicinal mushroom Lentinula edodes. Phytomedicine 15 (6-7): 512-519.

Kamal S. 2011. Quality Traits in Cultivation Mushrooms and Consumer Acceptability. Mushrooms-Cultivation, Marketing and Consumption (In: Singh M, Vijay B, Kamal S, Wakchure GC ed.). Directorate of Mushroom Research (ICAR) Chambaghat, Solan -173213, H.P., India.

Kansci G, Mossebo DC, Selatsa AB, Fotso M. 2003. Nutrient content of some mushroom species of the genus Termitomyces consumed in Cameroon. Die Nahrung 47 (3): 213-216.

Kaul TN, Dhar BL. 2007. Biology and Cultivation of Edible Mushrooms. Westville Publishing House. New Delhi.

King TA. 1993. Mushrooms, the ultimate health food but little research in U.S. to prove it. Mushr News 41: 29-46.

Kulshreshtha S, Mathur N, Bhatnagar P. 2014. Mushroom as a product and their role in mycoremediation (Mini Review. AMB Express 4: 29-36.

Kumari, R, Tapwal A, Pandey S, Borahi RK, Borahi D, Borgohaini J 2013. Macro-fungal diversity and nutrient content of some edible mushrooms of Nagaland, India. Nusantra Bioscience 5 (1): 1-7.

Lohani H. 2012. Training Manual on Mushroom Cultivation Technology. United Nations-Nations Unies Economic and Social Commission for Asia and the Pacific Asian and Pacific Centre for Agricultural Engineering and Machinery (APCAEM), Beijing-100029, P.R. China

Mabuza ML, Ortmann G, Wale E. 2014. Effects of transaction costs on mushroom producers' choice of marketing channels: Implications for access to agricultural markets in Swaziland. SAJEMS NS 17 (2): 207219.
Mallick SK, Maiti S, Bhutia SK, Maiti TK. 2010. Immunostimulatory properties of a polysaccharide Isolated from Astraeus hygrometricus. J Med Food 13 (3): 665-672.

Nanba H. 1993. Maitake mushroom- the king mushroom. Mushr News 41: 22-25.

NASS. 2005. 2005 Agricultural Statistic. National Agricultural Statistics Service, USDA-NASS, Washington, DC.

Noble R. 2005. Spent mushroom substrate -an alternative use. Amer Med Group Assoc J, Summer Issue: 33-35.

Pala SA, Wani AH. 2012. Mushrooms: The entities with multifarious medicinal properties. J Pharm Res 3 (12): 4721-4726.

Perry DA, Molina R, Amaranthus MP. 1987. Mycorrhizae, mycorrhizospheres, and reforestation: current knowledge and research needs. Can J For Res 17: 929-940.

Rojas C, Mansur E. 1995. Ecuador: Informaciones generales sobre productos non madereros en Ecuador In: Memoria, Consulta de Expertos Sobre Productos Forestales no Madereros para America Latina y el Caribe. Serie Forestal \#1, FAO Regional Office for Latin America and the Caribbean, Santiago, Chile.

Smith J, Rowan N, Sullivan R. 2002. Medicinal Mushrooms. Their Therapeutic Properties and Current Medical Usage with Special Emphasis on Cancer Treatment; Special Report Commissioned by Cancer Research UK. University of Strathclyde, Glasgow.

Stamets P. 2005. Mycelium Running: How Mushroom can Help Save the World. Ten Speed Press, Berkeley.

Suman BC, Sharma VP. 2007. Uses of mushrooms. In: Suman BC, Sharmas VP (eds.). Mushroom Cultivation and Uses. Daya Publishing House, Delhi, India.

Thatoi H, Singdevsachan SK. 2014. Diversity, nutritional composition and medicinal potential of Indian mushrooms: A review. Afr J of Biotech 13(4): 523-545.

UNFAOSTAT. 2011. United Nations, Food and Agriculture Organization Statistics, 2011. http: //faostat.fao.org/default.aspx. [14-01-2014]

Wang XM, Zhang J, Wu LH, Zhao YL, Li T, Li JQ, Wang YZ, Liu HG. 2014. A mini-review of chemical composition and nutritional value of edible wild-grown mushroom from China. Food Chem 151: 279-285.

Waseer SP. 2010. Medicinal mushroom science: History, current status, future trends, and unsolved problems. Int J Med Mush 12 (1): 1-16.

Wasser SP, Nevo E, Sokolov D, Reshetnikov S, Timor-Tismenetsky M. 2000. Dietary supplements from medicinal mushrooms: diversity of types and variety of regulations. Intl J Med Mush 2: 1-19.

Wasser SP, Weis AL. 1999. Medicinal properties of substances occurring in higher Basidiomycetes mushrooms: current perspectives (Review). Int J Med Mush 1: 1-62

Wasser SP. 2011. Current findings, future trends, and unsolved problems in studies of medicinal mushrooms. Appl Microbiol Biotechnol 89 (5): 1323-1332 